\title{
THE CASE FOR CORPORATE RESPONSIBILITY: ARGUMENTS FROM THE LITERATURE
}

\author{
LUCY DA PIEDADE \\ lucydapiedade@aol.com \\ ADẼLE THOMAS \\ adelet@uj.ac.za \\ Department of Human Resource Management \\ University of Johannesburg
}

\begin{abstract}
Heightened scrutiny of organisations and ever increasing stakeholder demands for organisations to respond to issues within broader society, make it imperative that organisational leaders understand why they should undertake corporate responsibility initiatives. This literature review (part one of a two part study) investigates the issues that should be addressed by organisations under the banner of corporate responsibility, including the definition of corporate responsibility, its extent and boundaries and the business case for corporate responsibility. This background provides a basis for an exploratory study (part two) of how South African organisations should frame
\end{abstract} the case for corporate responsibility and how investment in this area can be assessed.

\section{Key words}

Corporate responsibility, review initiatives, literature

\section{PROBLEM STATEMENT}

The recent spate of corporate failures and accounting scandals has undermined society's faith in corporate leadership, in financial reporting and in the integrity of markets the world over (Dowling, 2004; Witherell, 2002). In the past years, internationally and locally, demands have been made by corporate stakeholders to increase governance practices within organisations (Hollender, 2004; Paine, Deshpande, Margolis \& Bettcher, 2005; Zadek, 2004) and to include in corporate strategy, corporate responsibility initiatives that demonstrate organisational commitment to the greater good of society (Amalric \& Hauser, 2005; Hollender, 2004; Kennedy-Glans, 2005/06; Werther \& Chandler, 2004).

The notion of corporate responsibility or corporate citizenship is not easily defined (Grayson, 2005). Efforts have been made to translate social responsibility rhetoric into corporate action with more writers devoting their time to devising tools and methods of implementing the concept in organisations.

The range of issues that continue to be added to the 'corporate responsibility' sphere is ever-increasing, making it difficult for corporations to know what action to take and how to make a case for action in these areas. Changes in the environment in which organisations operate and debate around the accountability of business as a principal actor and motor for growth and development, opens the debate around the role of business in society. Defining the boundaries of responsibility of organisations in the face of failed states, poverty and lack of economic development is especially challenging in Africa today.

In Africa, Visser, Middleton and McIntosh (2005, p.18) note the role of business in a tripartite partnership with government and civil society to be focused at "aiding development towards a more participative, rule-of-law-based society where basic human rights and needs are met". Meeting such human rights involves poverty alleviation, improving governance, improving education, tackling corruption, enforcing labour standards, preventing resource depletion, controlling industrial pollution, promoting environmental conservation, upholding business ethics, ensuring the integrity of supply chains and addressing health issues such as HIV/AIDS (de Jongh, 2004; Visser, Middleton and McIntosh, 2005). In this regard, Visser, Middleton and McIntosh (2005) view a corporate citizenship or corporate responsibility debate as being integral to any debate on the future of Africa. Hamann, Kapelus, Sonnenberg, Mackenzie and Hollesen $(2005$, p. 61$)$ broaden this argument to stress the need for organisations working in Africa to proactively and creatively develop local collaborative structures within an "intricate and dynamic web of interrelated role-players involved in (un)sustainable development at the local level".

Hamann and Acutt (2003, p. 255), referring to corporate social responsibility in the South African context, note that it "is meant to link the market economy to sustainable development". Such sustainable development is arguably complimentary to economic development. Hamann (2003) notes that such initiatives necessarily must go beyond philanthropic investment to embrace developmental initiatives due to the country's history of apartheid and concomitant lack of previous state support for social development. Thus, the unique challenge to South African organisations is to address broader societal needs but to continue to generate profit to ensure that this happens (Middleton, 2005)

Visser (2005) notes the drivers of corporate social responsibility in South Africa to be legislation, globalisation of South African companies and concomitant subjection to international corporate governance requirements, stakeholder activism and adherence to global standards and codes including ISO 14001. The King Report on Corporate Governance (Institute of Directors, 2002) has also had widereaching impact with its recommendation that companies should report annually on the nature and extent of their social, ethical, transformation, safety, health and environmental practices, a recommendation that the Johannesburg Securities Exchange has made compulsory for companies wishing to list on the stock exchange. Sustainability reporting is now commonplace in South Africa with the publication of organisational initiatives on corporate performance in not only the economic sphere but also social and environmental performance, the so-called 'triple-bottom line' (Co-operative Insurance, 2002; Grayson, 2005; Institute of Directors, 2002; Vermeir, Van de Velde \& Corten, 2005; World Business Council for Sustainable Development, 2003).

It is advocated that the elements of corporate responsibility strategy in South Africa and the justification for that strategy should be studied with a view to comparing these to best practice and making recommendations to organisations.

As a background to begin to address these issues, a literature survey has been undertaken, highlighting the reasons why organisations do or should implement a corporate responsibility strategy. The literature review is divided into two sections. The 
first section offers debate on the definition of corporate responsibility. The second section is an exposition of the theory relating to the basis for arguments regarding the extent and boundaries of corporate responsibility and the consequent implications for the rationale of the business case.

\section{LITERATURE REVIEW}

\section{Defining corporate responsibility}

Corporate responsibility is a diffuse and continually evolving concept. Various definitions associate corporate responsibility with notions of governance, stakeholder theory, business ethics, sustainability, organisational culture and the relationship between business and society in general terms (Business for Social Responsibility, 2002; Ferrell, 2004; Grayson, 2005; Matten $\&$ Crane, 2005). Most scholars agree that there is no universally accepted definition of corporate responsibility or a definitive framework of how it should be applied (Carroll, 1979; Clarkson, 1995; Wood, 1991; Matten \& Crane, 2005).

Paradoxically, many organisations have embraced the terms 'corporate responsibility', 'corporate citizenship' and 'sustainable business' and have taken initiatives in this regard, although no consensus has emerged as to what the terms actually mean or imply (Carroll \& Buchholtz, 2000; Mirvis \& Googins, 2004).

The various definitions advanced attempt to answer the questions:

- to whom does business owe responsibility?

- what is business responsible for?

- who is calling for increased responsibility? (Moir, 2001).

The definition of corporate responsibility seems to have come a full circle. Descriptions of the term in the 1950s followed a philosophical approach in terms of which business is described as having responsibilities to society in the broadest sense (Bowen, 1953). Frederick (1994) confirms, in his analysis of the development of the area of study, that corporate responsibility, up to 1970 , was viewed in normative or philosophical terms as an obligation to work for social betterment. He refers to this stage as CSR1. This was followed by a managerial action-based approach often called corporate social responsiveness or what Frederick (1994) terms CSR2. By the late 1980s and early 1990s a return to an ethical or moral basis of informing managerial action followed, called corporate social rectitude or CSR3 (Moir, 2001). The many conflicting definitions and understandings of corporate responsibility that have been advanced have led some authors to recommend the abandonment, altogether, of the concept of 'corporate social responsibility', which is based on a language of rights and responsibilities.

Waddock (2002) argues that corporate responsibility is much more than 'social' and that the term 'corporate social responsibility' is inaccurate. "Thinking ... in terms of 'social' responsibility ... may allow companies to gain some positive public relations fluff, in the short run and will likely benefit some specific stakeholders. Ultimately, however, this narrow perspective allows organisations to get off the real responsibility hook, which has to do with how they are managed, what they produce, how they interact with the world" (Waddock, 2002, p. 20).

An argument has persisted in corporate responsibility circles for some time with regard to the use of the terms 'responsibility' and 'responsiveness'. Some writers have criticised the term 'responsibility' for attempting to reduce the argument to one of pinpointing accountability or obligation. Responsiveness, on the other hand, connotes a dynamic, action-oriented condition (Carroll \& Buchholtz, 2000). The advantage of the responsiveness orientation, in many instances, is that it allows organisations to operationalise their responsibilities without becoming sidetracked by the difficulty of defining exactly what the responsibilities of an organisation are in a particular case (Carroll \& Buchholtz, 2000).

Carroll (1979), an early pioneer in this area, developed the Corporate Social Performance Model, a forerunner to the Pyramid of Corporate Social Responsibility (Carroll, 1991) as represented in Figure 1, that integrates early thought on the three dimensions of corporate responsibility: 1) the social responsibility categories of economic, legal, ethical and discretionary; 2) the philosophy or mode of social responsiveness whether reactive, defensive, accommodative or proactive and 3 ) the social issues involved, namely consumerism, environment, discrimination and other issues which management must address in its corporate responsibility strategy. The advantage of the model is that it systematised and clarified the various dimensions and issues that were understood to form part of corporate responsibility.

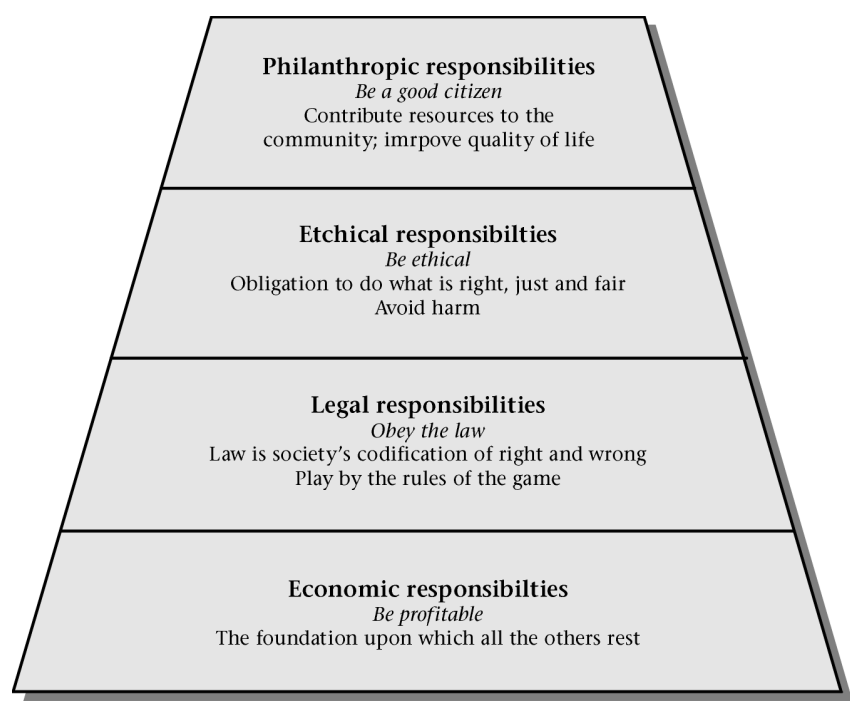

Figure 1: Carroll's (1991) Pyramid of Corporate Social Responsibility

This model highlights the necessity for organisations to simultaneously fulfil economic, legal, ethical and philanthropic responsibilities. It also indicates philosophical progression in social responsiveness from a reactive mode (where being profitable is paramount), through the modes of defensiveness and accommodation (where obeying the law and being ethical, respectively, are paramount) to a proactive mode where being a good citizen is the primary organisational motivator and which would encompass the previous levels.

The elements identified by Carroll $(1979 ; 1991)$ have later been amplified by Zadek (2004) who advocates an organisational learning model along the path to corporate responsibility from the defensive stage through to the civil stage where companies collectively address societal concerns.

Wartick and Cochrane (1985) built on Carroll's (1979) earlier work by adding three dimensions to the understanding of corporate responsibility. They envisioned these dimensions as principles that reflect the organisational dimension and issues that management identifies as important: philosophical orientation and processes; the institutional dimension of applying the philosophy; and policies.

More recently, calls have been made for a shift in the analytical framework of corporate responsibility to a new paradigmatic level based on the natural sciences and complexity theory. This framework seeks to move beyond the economic or corporationcentred orientation, and to re-introduce the normative or moral debate around the need for corporate responsibility (Aqueveque, 2005; Frederick, 1998; Hollender, 2004). 
Freeman and Liedtka (1991) suggest three alternative 'conversations' about organisations based on the understanding of the corporation as inextricably linked to society namely, the stakeholder proposition or the idea that organisations are connected networks of stakeholder interests; the caring proposition in terms of which organisations are understood to be places where individuals engage in caring activities aimed at mutual support and human achievement (organisation as community); and the pragmatist proposition that views organisations as means through which human beings are able to create and recreate their visions for self and community.

When considering the various ways of conceptualising corporate responsibility, it is suggested that an addition to the debate would be the extension of the philanthropic layer of the Carroll (1979; 1991) Model in the marrying of philanthropic and business foci. In this regard, organisations that, through interaction with stakeholders and relevant interaction with communities, are able to access information regarding stakeholder interests that may impact their organisations and who are able to translate this information into market awareness are equipped to build their competencies in learning, innovation and risk response (Grayson, 2005; Zadek, 2001; 2004).

Accordingly, a definition of corporate responsibility that is advanced is the commitment of organisations to act in the interest of both business and sustainable economic development based upon ethical values, compliance with legal requirements, and respect for and engagement with people, communities and the environment.

\section{THEORETICAL UNDERPINNINGS}

The extent and boundaries of and the business case for corporate responsibility

The following discussion highlights various evolving perspectives regarding the nature and extent of corporate responsibility and forms the basis of how corporate responsibility is embraced, as a business case, within organisations.

\section{Neo-classical perspective}

According to the neo-classical or, what Locke (http:mitsloan.mit.edu/50th/corpcitizenship) calls, the minimalist theory of corporate responsibility, the responsibility of business is to ensure optimal economic performance of corporations in order to increase shareholder wealth. Those who adopt the neo-classical view of the organisation advocate that the only responsibilities to be taken on by business are the provision of employment and the payment of taxes (Moir, 2001). This view holds that a society can best determine its needs and wants through the invisible hand of the marketplace (Carroll \& Buchholtz, 2000). The leading proponent of this view, Milton Friedman (1970), argues that organisations, as artificial persons, cannot have social responsibilities. He maintains that the principal responsibility of organisations is towards their shareholders; to increase their wealth while conforming to the basic rules of society, both those embedded in law and those embedded in ethical custom. When corporate executives engage in socially responsible activities that are not required of them in terms of prevailing laws and customs, these actions constitute a tax on the organisation.

One could argue that Friedman's (1970) arguments have been interpreted too narrowly and that reference to the ethical customs of the time must surely mean that changing expectations about the roles of business in society need to be taken into account. However, the most common interpretations of Friedman's statements are that in a democratic society, government is the only legitimate vehicle for addressing social concerns and that business' involvement in this respect should be curtailed (Carroll \& Buchholtz, 2000). Levitt (1958, p. 47) also warned about the dangers of adopting corporate responsibility criteria, noting, “... welfare and society are not the corporation's business. Its business is making money not sweet music". Similarly Korten (1997) has argued that ethical organisations are necessarily pushed out of a competitive market and Zadek (2004) notes that being 'good' does not always pay.

\section{Legal perspective}

The neo-classical model evolved further when laws constraining business behaviour began to proliferate in response to changed societal expectations from being strictly economic in nature to encompassing aspects that had previously been left to the discretion of organisations (Carroll \& Buchholtz, 2000). A formalistic legal interpretation was taken by some scholars who were concerned with the distinction between those obligations mandated by law and those that were taken on a discretionary basis (Davis, 1973; Sethi, 1979). The philosophy of legal pragmatism developed in opposition to the legal formalistic approach that establishes that law is not merely those rules that are formally codified. Laws are instruments of social policy. This philosophy holds that laws evolve organically and require managers to exercise discretion in the interpretation of the social spirit of the law (Foote, 1984; Ostas, 2001). Most commentators agree, however, that legislation in itself cannot increase socially responsible behaviour and that organisations should work towards developing a culture of corporate responsibility (Caldini, Petrova \& Goldstein, 2004; Morrison, 2001; Sarre, Doig $\&$ Fiedler, 2001; Weaver, 2001).

\section{Philanthropic perspective}

This concept is predicated on the notion of charity, requiring more fortunate members of society to assist the less fortunate, and stewardship requiring businesses and wealthy individuals to act as stewards or caretakers of property, holding it in trust for society as a whole (Frederick, 1994; Freeman \& Liedtka,1991). Philanthropic action is taken on a discretionary basis and is motivated by moral and/or religious arguments (Carroll, 1991). Carroll and Buchholtz (2000) note that the adoption of a paternalistic and philanthropic approach to community involvement was precipitated by the emergence in the late $1800 \mathrm{~s}$ of large corporations in America that changed the balance of power between society and business, and raised the issue of the responsibility of these organisations to the societies in which they operated. However, the idea remains rooted in the economic concept of business as wealth generator and not societal actor.

\section{Stakeholder perspective}

According to this view, the responsibility of business encompasses more than its primary economic duty to shareholders; business has a duty to other stakeholders as well. The 'narrow sense of stakeholder' refers to any identifiable group or individual on which the organisation is dependent for its continued survival (Ferrell, 2004; Freeman \& Reed, 1983). Freeman (1984, p. 46) defines a stakeholder as "any group or individual who can affect or is affected by the achievement of the organization's objectives". Primary stakeholders are generally understood to be shareholders, investors, employees, customers and suppliers (Clarkson, 1995; Dowling, 2004) together with what is defined as the 'public stakeholder group' namely, "government and communities which provide infrastructure and markets, whose laws and regulations must be obeyed, and to whom taxes and obligations are due" (Clarkson, 1995, p. 106). A high level of interdependence exists between primary stakeholders and the organisation, since damage to this relationship affects the survival of the organisation (Aqueveque, 2005; Dowling, 2004; Werther \& Chandler, 2004). Some writers take a narrower view of the stakeholder concept as being those stakeholders without whose continuing participation the organisation cannot survive as a going concern. 
A broader view of stakeholder is based on the premise that organisations have a responsibility to society beyond their primary stakeholders. Opinions regarding the extent of this responsibility vary. Freeman (1984) subscribes to a 'wide sense of stakeholder', which includes any individual who can affect or who is affected by the achievement of an organisation's objectives. Other theorists believe that companies are forced into a broader notion of stakeholders due to increasing pressure being put on companies by secondary stakeholders such as activists, non-governmental organisations, communities and other governments (Amalric \& Hauser, 2005; Mirvis \& Googins, 2004; Waddock, Bodwell \& Graves, 2002). Most organisations and corporate responsibility proponents appear to define corporate responsibility from a stakeholder perspective based on analysis and engagement (Epstein,1987; Frederick,1998; Jones, 1980). Managers are faced with the challenge of determining who their stakeholders are and to which of their demands or needs they should respond. Mitchell, Agle and Wood (1997) developed a model of stakeholder identification and salience based on stakeholder attributes of power, legitimacy and urgency. Based on this model organisations would be expected to pay the most attention to legitimate stakeholder groups who have power and urgency (Moir, 2001).

Ferrel (2005), Hall and Vredenburg (2005) and Zadek (2001) also distinguish between 'negotiated boundaries', in terms of which organisations determine the stakeholders with whom they should negotiate; 'evolving boundaries', which are dependent on constant learning and re-evaluation; 'standard boundaries', which refer to the host of international reporting standards and guidelines that prescribe the extent of corporate responsibility and, 'committed boundaries', which are those elements of corporate responsibility that are integral to a particular direction to which the organisation has committed itself.

\section{Broad societal perspective}

In terms of this perspective, the boundaries of corporate responsibility are extended beyond those groups directly affected by organisational decision-making. The premise is that organisations have a moral or ethical duty to enhance broader societal goals. Mahon and McGowan (1991, p.81), in accordance with other more recent writers on the topic (Werther \& Chandler, 2004; Zadek, 2004), hold this broader understanding of stakeholders and conclude: " ... it is clear that most authors mean corporate social responsibility to include behavior and actions beyond mere profit making that serve to improve the conditions of society and individuals within that society". Corporate social responsibility in this instance is motivated by a recognition that long term viability of organisations depends upon the prosperity of the environment in which they operate (Mahon \& McGowan, 1991; Werther \& Chandler, 2004; Zadek, 2004). This view is reflected in Zadek's (2001; 2004) Third Generational Theory of Corporate Responsibility that seeks to address the question of the extent of business responsibility for addressing social and environmental problems.

Moir (2001), and later Grayson (2005), remark that corporate responsibility covers an ever-increasing range of issues such as plant closures, employee relations, human rights, corporate ethics, community relations and the environment to which can be added the aforementioned issues pertinent to South Africa such as HIV/AIDS, environmental protection and sustainability. Hall and Vredenburg (2005) and Zadek $(2001 ; 2004)$ argue that traditional and legal obligations are increasingly inadequate bases for defining the extent and boundaries of organisational responsibility. They distinguish between the legal, financial and operational methods of defining the boundaries of corporate responsibility and the more recent methods of characterising corporate boundaries in terms of strategy, risk, value chains, information, knowledge and values.

The following three theories emerge from the broad stakeholder and societal perspectives.
Social contracts theory

Viewing society as a series of social contracts presents an alternative view of why organisations need to act responsibly (Gray, Owen \& Adams, 1996; Grayson, 2005). Organisations that adopt the social contract view explain their involvement in responsibility projects in terms of societal expectation. Donaldson and Dunfree (1999) have developed an integrated model based on the theory of social contracts for manager decision-making in an ethical context. They distinguish between macro and micro social contracts. The macro social contract will determine in which areas organisations need to get involved, whereas the micro social contract indicates the specific involvement and responsibility programmes. Moir (2001) remarks that although social contract theory may explain the initial motivation of organisations in becoming involved in corporate responsibility, it probably does not explain the totality of its involvement and has to be understood in the context of the other theories such as legitimacy theory.

\section{Legitimacy theory}

Organisations often seek to legitimise their activities through communicating the benefits of their involvement and changing perceptions about their business. Zadek (2004) equates this to an organisation being at a 'strategic' stage of learning. Suchman (1995) identifies three challenges to legitimacy management namely: gaining, maintaining and repairing legitimacy. The success or failure of legitimacy management initiatives relies heavily on communication and the effectiveness of corporate communications. Lindblom (1994) notes that organisations do not have to follow a passive approach in seeking to gain legitimacy, but can employ four broad legitimating strategies when faced with threats: 1) seek to educate stakeholders about the intentions of the organisation to improve performance; 2 ) seek to change the organisation's perceptions of the event; 3) distract attention away from the issue of concern; and 4) seek to change external expectations about its performance.

Organisations not only earn legitimacy but are expected to use the power granted to them responsibly or such power will be withdrawn by society (Zadek, 2004).

\section{Enlightened value maximisation theory}

Amalric and Hauser (2005) and Jensen (2001) argue that the maximisation of the long-term value of the organisation is the criterion for making the necessary trade-offs among various stakeholder interests. In Jensen's analysis, value maximisation provides managers with a single objective that is necessary for purposeful behaviour. His criticism of stakeholder theory is that it contains no conceptual specification as to how to make tradeoffs between the competing, and often conflicting, interests of various stakeholders. The basic premise of enlightened value maximisation is that "we cannot maximize the long-term market value of an organisation if we ignore or mistreat any important constituency" (Jensen, 2001, p.16). Value maximisation gives management a way to assess trade-offs and demands and it allows for principled decision-making independent of personal preferences of managers and directors. In terms of this theory, managers and employees are motivated to seek value by instituting those changes and strategies that are most likely to increase organisational value.

Grayson and Hodges (2001) comment that organisations are often confused about where to draw the line on their external involvement and should be guided by cultural and societal norms about the role of business in the community in particular regions. They recommend that managers focus on community issues where there is a direct link to business needs, an interest among employees, relevant corporate expertise and other resources that can be deployed. As Moir (2001, p. 17) states: "whether or not a business should undertake CSR, and the forms that responsibility should take, depends upon the economic perspective of the firm". 
The business case for corporate responsibility

Although the concept of corporate responsibility has received significant support, it has proven difficult to quantify in costbenefit and other traditional financial terms what the contribution of corporate responsibility practices to profitability is (Martin, 2002; Vogl, 2003, Zadek, 2004). However, supporters of corporate responsibility standards often point to the fact that most business decisions are taken without an explicit cost-benefit analysis (Vogl, 2003). According to Zadek (2001) it is an insistence on a 'win-win' proposition that lies at the heart of the confusion over the role and impact of business in society.

Research regarding the relationship between corporate responsibility and financial performance appears inconclusive. Some researchers have found a positive relationship between these two variables (Almaric \& Hauser, 2005; Anderson \& Frankle, 1980; Aqueveque, 2005; Bowman \& Haire, 1975; Bragdon \& Marlin, 1972; Chiang \& Chia, 2005; Hall \& Vredenburg, 2005; Ingram, 1978; Klein, Smith \& John, 2004; McKinsey, 2002; Moskowitz, 1972; Orlitsky, 2005; Preston, 1975; Spicer, 1978; Sturdivant \& Ginter, 1977; Vermeir et al., 2005). Others have found no link between the variables (Abbott \& Monsen, 1979; Aupperle, Carroll \& Hatfield, 1985). Questions are, however, raised regarding the methodology applied in these studies, particularly with regard to the measures of financial performance and corporate responsibility respectively. Some researchers have found corporate responsibility to be inversely linked with profitability in the short run (Vance, 1975). Some have pointed to the fact that organisations that are good corporate citizens also tend to do well financially since good corporate responsibility management is often an indicator of sophisticated management throughout the organisation (Ringger, 1999).

Aupperle et al. (1985) conclude that the issue of whether corporate responsibility is related to financial performance will never be completely resolved.

According to Grayson and Hodges (2001) a business case is normally articulated as a positive or negative argument for action or inaction, as a cost or loss, or as a saving or a gain in relation to something of value to the organisation. Value can be measured in terms of market share, reputation, employee morale and performance, relationships with business partners and the cost of capital. Most writers and practitioners agree that there is no single business case for corporate citizenship (Grayson \& Hodges, 2001; Zadek, 2004). In many instances the corporate responsibility strategy will depend on where the organisation is in its life cycle (Grayson \& Hodges, 2001), whether there are cost-benefit advantages, what the risks are to the organisation that need to be managed and whether the organisation has considered the strategic long term viability of the organisation and the linkage of its competitive advantage to the understanding and management of its various stakeholders.

When preparing to make a business case for corporate responsibility, Grayson and Hodges (2001) recommend one of two approaches, namely, building the argument from an 'emerging issues' perspective or from a 'business needs' perspective. Emerging issues are normally presented as either risks or opportunities. Emerging management issues include: ecology and the environment, health and well-being, diversity and human rights and communities. A 'business needs' perspective includes the building of people such as recruiting and retaining employees, building the organisation in terms of reducing risks and costs and finally building reputation. Reputational issues include building goodwill and a licence to operate.

Organisations are often required to adopt corporate responsibility practices in order to be recognised as trustworthy partners in long-term strategic relationships (Pearson, 2000) and because the society within which they operate expects this
(Mirvis \& Googins, 2004). Heightened interest on the part of investors, consumers and other stakeholders in the issues encompassed in corporate responsibility means that failure to address these issues may result in a number of negative outcomes. A study by the World Business Council for Sustainable Development (2000) points to several actions that may seriously damage corporate reputation and also translate into negative financial repercussions. These include, consumer boycotts, attacks on fixed assets, loss of employee support, unanticipated spending in order to remedy mistakes, diversion of management attention from core activities and barriers to raising finance or insurance. Increasingly these issues are becoming more important to investors (Co-operative Insurance, 2002; Dowling, 2004). A study conducted by McKinsey and Company (2002), found that institutional investors in emerging markets are willing to pay a premium for investments in companies that maintain good governance practices. Regional trading blocs are including Social Impact Assessments in their trading policy with other nations in order to ensure that corporate responsibility principles are incorporated into trade and development agreements (European Commission, 2003).

Zadek $(2001 ; 2004)$ breaks the business case down into four broad (and interrelated) categories namely: defence or pain alleviation (the defensive stage), the traditional or cost-benefit case (the compliance stage), the strategic case and the new economy business case (the civil stage). In the first two stages, the organisation is reactive, taking only those measures that comply legally or that may satisfy basic stakeholder requirements. Such compliance may be able to be measured (e.g. an absence of safety-related accidents or an absence of legal penalties). Where an organisation makes a strategic business case, corporate responsibility becomes an integral element of the broader strategic approach of the organisation to long-term organisational performance. Unlike the defensive or traditional case, the strategic approach cannot easily be subjected to a standard financial cost-benefit analysis. The new economy business case or civil stage involves learning, innovation and risk management of acquiring and acting on stakeholder information in a way that builds new competencies or products in the organisation, and provides innovative ideas about how to manage risk and increase profits (Waddock \& Smith, 2000; Zadek, 2001; 2004). De Jongh (2004, p.28) highlights the challenges of managing social risk in South Africa and states that "... in a country such as South Africa, where the socio-economic and socio-political landscape is transforming at an everincreasing pace, sound judgement, stakeholder engagement and cross-sector partnership seem to be the only workable solutions to managing social risk". In line with adopting a new economy business case, innovative business ideas have arisen from initiatives to service the poor and there is an increasing realisation that sustainable business need not be unprofitable business (Handy, 2002; Hart, 1997; Prahalad \& Hart, 2002).

Roberts, Keeble and Brown (2002) report eight areas of business benefit associated with corporate responsibility, namely, sound reputation management particularly in view of the fact that value derived from intangible assets is high and reputation is often the most valuable of these assets; risk management; employee recruitment, motivation and retention; investor relations and access to capital; learning and innovation in that corporate responsibility objectives encourage creativity; competitiveness and market positioning; operational efficiency by means of reductions in waste and negative environmental impact, and maintaining a licence to operate which may be in jeopardy when an organisation develops a reputation as a bad corporate citizen.

Grayson and Hodges (2001) point to an alternative way of developing the organisation by basing it on building people, the business and the corporate reputation. Under building people they refer to attracting, retaining and developing talent and 
assert that people increasingly wish to work for organisations that share their personal values. Investing money in response to issues such as protection of the environment ultimately saves costs associated with litigation and clean up operations. In the same way, a well-planned promotion of a diversity programme can avoid legal challenge.

The case for responsible corporate practices may only be discernable when a longer-term view of business is applied and the sustainability of an organisation is evaluated. Zadek (2001) refers to the corporate citizenship 'Mecca' in terms of which organisations adopt a corporate responsibility strategy as part of their overall organisational strategy aimed at increasing their competitive advantage and changing the way in which organisations do business.

While it may be possible to gain financially by adopting corporate responsibility practices through, for example, its impact on employee retention and productivity, customer loyalty and effective risk and reputation management, the business case is not always easy to make since it is possible to do good and not see benefits, or for such initiatives to detract from core business operations.

Zadek (2001) raises a further dilemma in that 'viable well-doing' will not be sufficient to meet the world's challenge of sustainable development. He questions whether corporate responsibility should stretch only as far as the limits of the business case, the so called 'Oasis' of responsibility, or whether there is an underlying moral or ethical imperative for organisations to become more responsible. Currently in most organisations, business strategies and operations are aligned with certain sustainable development objectives such as the addressing of HIV/AIDS or the provision of social housing to employees, but do not attempt to tackle broader societal issues that would change the business environment (Zadek, 2001) or go beyond the business case to fundamentally change society (Hollender, 2004). Forstater (2002) notes the difficulty of making a business case 'below the breadline' in poor regions where the traditional business case arguments fall apart in the face of endemic poverty. She concludes that the challenge of poverty in Africa demands that one should go beyond corporate responsibility 'as usual'.

\section{DISCUSSION AND RECOMMENDATIONS}

In recent years pressure has been placed on organisations, internationally and in South Africa, to focus on good corporate citizenship. Diffuse concepts have emerged such as 'corporate citizenship', 'corporate social responsibility' 'corporate social investment' and 'corporate responsibility', with little agreement on definitions or what initiatives fall, ideologically, within the ambit of the respective concepts.

This paper advocates a definition of corporate responsibility that goes beyond philanthropy to combine a focus on business and sustainable development based on values, legal compliance and stakeholder engagement. This thinking is in line with what can be thought of as some of the challenges to South African organisations in the area of corporate responsibility.

Emerging issues such as poverty alleviation, improving governance, improving education, tackling corruption, enforcing labour standards, preventing resource depletion, controlling industrial pollution, promoting environmental conservation, upholding business ethics, addressing health issues such as HIV/AIDS, building human capital and promoting economic development are now growing in topicality in South African debate. These issues, it is suggested, are those that organisations operating in emerging markets, such as South Africa, need to focus upon in order to demonstrate that they are adding value in their business environments.
Determining the extent and nature of corporate responsibility in South Africa begs answers to the questions: What is the role of business in this regard? and, what can and should society expect from the business community in addressing the imperatives and aspirations underpinning sustainable development? Once it is established what organisations should be doing, an equally important question is: how should these expectations be realised in practice?

Based on the preceding discussion, and given the increasing South African debate on 'triple bottom line' organisational reporting on economic, social and environmental issues (Institute of Directors, 2002), the following propositions are posited for further study:

- Proposition No 1:

South African companies do not incorporate into their corporate responsibility strategies, issues that are critical to sustainable business such as HIV/AIDS, economic development and education (de Jongh, 2004; Hamann, 2003; Hamann and Acutt, 2003; Visser, Middleton and McIntosh, 2005).

- Proposition No 2:

South African companies base their case for corporate responsibility mainly on defensive or cost-benefit arguments (Zadek 2001; 2004).

- Proposition No 3:

South African companies develop corporate responsibility strategies in order to promote innovation and learning and risk management (de Jongh, 2004; Waddock \& Smith, 2000; Zadek, 2001; 2004).

Although there is a lack of consensus with regard to the extent of corporate responsibility and where the responsibility of business ends and that of government begins (World Business Council on Sustainable Development, 2003), the potential benefits that can be gained from an effective corporate responsibility strategy are such that this area warrants further research attention, especially with a view to delineating those aspects or corporate responsibility that should command South African business attention.

\section{REFERENCES}

Abbott, W.F.\& Monsen, J.R. (1979). On the measurement of corporate social responsibility: Self reported disclosures as a method of measuring corporate social involvement. Academy of Management Journal, 22 (3), 501-515.

Amalric, F. \& Hauser, J. (2005). Economic drivers of corporate responsibility activites. The Journal of Corporate Citizenship, winter, 20, 27-38.

Anderson, J.C. \& Frankle, A.W. (1980). Voluntary social reporting: An iso-beta portfolio analysis. The Accounting Review, 55 (3), 467-479.

Aqueveque, C. (2005). Marketing and market development: Signalling corporate values - consumers' suspicious minds. Corporate Governance, 5 (3), 467-479.

Aupperle, K.E., Carroll, A.B. \& Hatfield, J.D. (1985). An empirical examination of the relationship between corporate social responsibility and profitability. Academy of Management Journal, 28 (2), 446-463.

Blyth, A. (2002). Investing in Africa, challenges and initiatives. Ethical Corporation, November, 26-30.

Bowen, H.R. (1953). Social responsibilities of the businessman. New York: Macmillan.

Bowman, E.H. \& Haire, M.A. (1975). A strategic posture towards corporate social responsibility. California Management Review, 18 (2), 49-58.

Bragdon, J. \& Marlin, J. (1972). Is pollution profitable? Risk Management, April, 9-18. 
Business for Social Responsibility (2002). Overview of corporate social responsibility. http:www.bsr.org/BSRResources/ IssueBriefDetail.cfm?DocumentID=48809 (accessed 14 May 2003)

Caldini, R.B., Petrova, P.K. \& Goldstein, N.J. (2004). The hidden costs of organizational dishonesty. Sloan Management Review, Spring, 67-73.

Carroll, A.B. (1979). A three-dimensional model of corporate performance. Academy of Management Review, 4 (4), 497-505.

Carroll, A.B. (1991). The pyramid of corporate social responsibility: Toward the management of organizational stakeholders. Business Horizons, 34 (4), July-August, 39-49.

Carroll, A.B. \& Buchholtz, A.K. (2000). Business \& Society. Fourth edition, Cincinnati: South-Western College Publishing.

Chiang, H.T. \& Chia, F. (2005). An empirical study of corporate governance and corporate performance. Journal of American Academy of Business, 6 (1), 95-101.

Clarkson, M.B.E. (1995). A stakeholder framework for analyzing and evaluating corporate social performance. Academy of Management Review, 20 (1), 92-117.

Cochran, P.L. \& Wood, R.A. (1984). Corporate social responsibility and financial performance. Academy of Management Journal, 27 (1), 42-56.

Co-operative Insurance (2002). Sustainability pays. http://www.cis.co.uk/socacc2002/pdf/SusPays.pdf (accessed 7 January 2004).

Davis, K. (1973). The case for and against business assumption of social responsibilities. Academy of Management Journal, 16 (2), 312-322.

de Jongh, D. (2004). A stakeholder perspective on managing social risk in South Africa: Responsibility or accountability? The Journal of Corporate Citizenship, Autumn (15), 27-31.

Donaldson, T. \& Dunfee, T.W. (1999). Ties that bind. Boston: Harvard Business School Press.

Dowling, G.R. (2004). Corporate reputations: Should you compete on yours? California Management Review, 46 (3), 19-36.

Environics International (2002). Global CSR Monitor. http://www.globescan.com.

Epstein, E. M. (1987). The corporate social policy process: Beyond business ethics, corporate social responsibility and corporate social responsiveness. California Management Review, 29 (3) Spring, 99-114.

European Commission (2003). Getting returns on social responsibility. CSR Magazine, 2 (2) 12-15.

Ferrell, O. (2004). Business ethics and customer stakeholders. Academy of Management Executive, 18 (2), 126-129.

Foote, S.B. (1984). Corporate responsibility in a changing legal environment. California Management Review, 26 (3), Spring, 217-228.

Forstater, M. (2002). What can corporate responsibility do in the fight against poverty in Africa? Ethical Corporation Magazine, November, 37-40.

Frederick, W.C. (1994). From CSR1 to CSR2: The maturing of business and society thought. Business and Society, 33 (2), August, 150-167.

Frederick, W.C. (1998). Creatures, corporations, communities, chaos, complexity: A naturological view of the corporate social role. Business and Society, 37 (4), December, 358-389.

Freeman, E.R. (1984). Strategic management: A stakeholder approach. Boston: Pitman Publishing.

Freeman, E.R. \& Liedtka, J. (1991). Corporate social responsibility: A critical approach. Business Horizons, 34 (4), July-August, 92-99.

Freeman, E.R. \& Reed, D.L. (1983). Stockholders and stakeholders: A new perspective on corporate governance. California Management Review, 25 (3), Spring, 88-106.

Friedman, M. (1970). The social responsibility of business is to increase its profits. The New York Times Magazine, 13 September, 137-141.

Gorte, J.F. (2005). Corporate social responsibility: Close to victory. Journal of Investing, 14 (3), 140.
Gray, R., Owen, D., \& Adams, C. (1996). Accounting and accountability: Changes and challenges in corporate social and environmental reporting. Harlow: Prentice-Hall Europe.

Grayson, D. (2005). From responsibility to opportunity. Corporate Responsibility Management, 2 (2), 34-37.

Grayson, D. \& Hodges, A. (2001). Everybody's business. First edition, London: Dorling Kindersley Limited.

Hall, J. \& Vredenburg, H. (2005). Managing stakeholder ambiguity. MIT Sloan Management Review, 47 (1), 11-13.

Hamann, R. 2003. Mining companies' role in sustainable development: The 'why' and the 'how' of corporate social responsibility from a business perspective. Development Southern Africa, 20 (2), 237-254.

Hamann, R. \& Acutt, N. (2003). How should civil society (and the government) respond to 'corporate social responsibility'? A critique of business motivations and the potential for partnerships. Development Southern Africa, 20 (2), 255-270.

Hamann, R., Kapelus, P., Sonnenberg, D. , Mackenzie, A. \& Hollesen, P. (2005). Local governance as a complex system. Lessons from mining in South Africa, Mali and Zambia. The Journal of Corporate Citizenship, Summer (18), 61-73.

Handy, C. (2002). What's a Business For? Harvard Business Review, 8 (12), 49-55.

Hart, S. L. (1997). Beyond greening: Strategies for a sustainable world. Harvard Business Review, January, 75 (1), 66-76.

Hollender, J. (2004). What matters most: corporate values and social responsibility. California Management Review, 46 (4), $111-119$

Ingram, R.W. (1978). An investigation of the information content of (certain) social responsibility disclosures. Journal of Accounting Research, 16, 270-285.

Institute of Directors (2002). King Report on Corporate Governance for South Africa. Johannesburg: IOD.

Jensen, M.C. (2001). Value maximization, stakeholder theory and the corporate objective function. Journal of Applied Corporate Finance, 14 (3), 8-21.

Jones, T.M. (1980). Corporate social responsibility revisited, redefined. California Management Review, Spring, 12 (2), 5967.

Kennedy-Glans, D. (2005/06). Achieving a single ethical standard in a globalized world. Corporate Responsibility Management, 2 (3), 24-29.

Kline, J.G., Smith, N.C. \& John, A. (2004). Why we boycott: Consumer motivations for boycott participation. Journal of Marketing, 68 (3), 92-109.

Korten, D. (1997). When corporations rule the world. West Hartford, Connecticut: Kumarian.

Levitt, T. (1958). The dangers of social responsibility. Harvard Business Review, Sept-Oct, 36 (5), 41-50.

Lindblom, C.K. (1994). The implications of organisational legitimacy for corporate social performance and disclosure. Paper presented at the Critical Perspectives on Accounting Conference, New York, NY.

Locke, R.M. (undated). Note on corporate citizenship in a global economy. http://mitsloan.mit.edu/50th/corpcitizenship.pdf (accessed 2 May 2003).

Mahon, J.F. \& McGowan, R.A. (1991). Searching for the common good: A process oriented approach. Business Horizons, 34 (4), July-August, 79-87.

Matten, D. \& Crane, A. (2005). Corporate citizenship: Toward an extended theoretical conceptualisation. Academy of Management Review, 30 (1), 166-179.

Martin, R.L. (2002). The virtue matrix, calculating the return on corporate responsibility. Harvard Business Review, March, 511.

McKinsey \& Company (2002). Investor opinion survey on corporate governance. London: McKinsey \& Company.

Middleton, C. (2005). Interview with Michael Spicer, Chief Executive, South Africa Foundation. The Journal of Corporate Citizenship, Summer (18), 21-24.

Mirvis, P. \& Googins, B. (2004). The best of the good. Harvard Business Review, December, 1-2. 
Mitchell, R.K., Agle, B.R. \& Wood, D.J. (1997). Toward a theory of stakeholder identification and salience: Defining the principle of who and what really counts. Academy of Management Review, 22, 853-886.

Moir, L. (2001). What do we mean by corporate social responsibility? Corporate Governance, 1 (2), 16-22.

Morrison, A. (2001). Integrity and global leadership. Journal of Business Ethics, 31, 65-76.

Moskowitz, M. (1972). Choosing socially responsible stocks. Business and Society Review, 1, 71-75.

Orlitsky, M. (2005). Payoffs to social and environmental performance. Journal of Investing, 14 (3), 48-52.

Ostas, D.T. (2001). Deconstructing corporate social responsibility: Insights from legal and economic theory. American Business Law Journal, 38 (2), 261-300.

Paine, L., Deshpande, R, Margolis, J.D. \& Bettcher, K.E. (2005). Up to code: Does your company's conduct meet world-class standards? Harvard Business Review, December, 122-133.

Pearson, G. (2000). Making profits and sweet music. Business Ethics: A European Review, 9 (3), July, 191-199.

Petersen, R. (2005). Responding to changing stakeholder expectations. Marketing, June, S8.

Prahalad, C.K. \& Hart, S.L. (2002). The fortune at the bottom of the pyramid. Strategy \& Business, 26 (1), 55-67.

Preston, L.E. (1975). Corporation and Society: The search for a paradigm. Journal of Economic Literature, 13, 434-453.

Ringger, R. (1999). Editorial. International Herald Tribune, 22 September, 24.

Roberts, S. \& Keeble, J. \& Brown, D. (2002). The business case for corporate citizenship.

http:www.csrwire.com/pdf/Business-Case-for-CorporateCitizenship.pdf (accessed 10 May 2003).

Sarre, R., Doig, M. \& Fiedler, B. (2001). Reducing the risk of corporate irresponsibility: The trend to corporate social responsibility. Accounting Forum, 25 (3), September, 300-317.

Sethi, S.P. (1979). A conceptual framework for environmental analysis of social issues and evaluation of business response patterns. Academy of Management Review, 4 (1), 63-74.

Spicer, B.H. (1978). Investors, corporate social performance and informational disclosure: An empirical study. Accounting Review, 53 (1), 94 -111.

Sturdivant, F.D. \& Ginter, J.L. (1977). Corporate social responsiveness, management attitudes and economic performance. California Management Review, 19 (3), Spring, 30-39.
Suchman, M.C. (1995). Managing legitimacy: Strategic and institutional approaches. Academy of Management Review, 20, 571-610

Vance, S.C. (1975). Are socially responsible corporations good investment risks? Management Review, August, 18-24.

Vermier, W., Van de Velde, E. \& Corten, F. (2005). Sustainable and responsible performance. Journal of Investing, 14 (3), 9499.

Visser, W., Middleton, C. \& McIntosh, M. (2005). Introduction The Journal of Corporate Citizenship, Summer (18), 18-20.

Vogl, A.J. (2003). Does it pay to be good? Across the Board, Jan/Feb, 16-23.

Waddock, S. (2002). Corporate responsibility is not social. Ethical Corporation Magazine, November, 20-21.

Waddock, S.A., Bodwell, C. \& Graves, S.B. (2002). Responsibility: The new business imperative. Academy of Management Executive, 16 (2), 132-150.

Waddock, S. \& Smith, N. (2000). Corporate responsibility audits: Doing well by doing good. Sloan Management Review, Winter, 75-82.

Wartick, S. L, \& Cochrane, P.L. (1985). The evolution of the corporate social performance model. Academy of Management Review, 10, 758-769.

Weaver, G.R. (2001). Ethics programs in global businesses: Culture's role in managing ethics. Journal of Business Ethics, 30 (1), 3-16.

Werther, W.B. \& Chandler,D. (2004). Strategic corporate social responsibility as global brand insurance. Business Horizons $48,317-324$.

Witherell, B. (2002). Corporate governance and responsibility Foundations of market integrity. OECD Observer, 234 October, 7-9.

Wood, D. (1991). Corporate social performance revisited Academy of Management Review, 16 (4), 691-718.

World Business Council for Sustainable Development (2000). CSR: making good business sense. http:www.wbcsd. ch/DocRoot/5 mbUksfWpqAgPpPpUq/Ue/csr2000.pdf (accessed 13 May 2004).

World Business Council for Sustainable Development (2003). Sustainable development reporting: Striking the balance. http:www.wbcsd.ch/DocRoot/GGFpsq8dGngT5K56sAW/200 30106_sdreport.pdf (accessed 13 May 2004).

Zadek, S. (2001). The civil corporation, the new economy of corporate citizenship. First edition. London: Earthscan Publications.

Zadek, S. (2004). The path to corporate responsibility. Harvard Business Review, December, 1-8. 